\title{
Produksi senyawa metabolit sekunder dari tumbuhan obat
}

\author{
Aliefman Hakim ${ }^{1 *}$, A. Wahab Jufri ${ }^{1}$ \\ ${ }^{1}$ FKIP, Universitas Mataram, Mataram \\ aliefmanhakim27@gmail.com
}

\begin{abstract}
Secondary metabolites were needed by researchers as raw materials for drugs, raw materials for synthesis of target molecules, bioactive compounds and model compounds. But until now, there were no producers that supply secondary metabolite compounds in Indonesia, so it is very difficult to find them in the domestic market. The need for secondary metabolite compounds has been purchased from abroad at very high prices. On the other hand, Indonesia has a lot of plant diversity which is the source of secondary metabolite compounds. Modification of several procedures for isolation of secondary metabolites has been carried out in the framework of the production of secondary metabolites.
\end{abstract}

Keywords: production; secondary metabolites; medicinal plants

\begin{abstract}
Abstrak
Senyawa metabolit sekunder sangat diperlukan oleh peneliti sebagai bahan baku obat, bahan baku sintesis molekul target, senyawa bioaktif dan senyawa model. Namun sampai saat ini, belum ada produsen yang memasok senyawa metabolit sekunder di Indonesia, sehingga sangat sulit menemukannya di pasar dalam negeri. Kebutuhan akan senyawa metabolit sekunder selama ini dibeli dari luar negeri dengan harga yang sangat mahal. Dilain pihak, Indonesia memiliki banyak keanekaragaman tumbuhan yang menjadi sumber dari senyawa metabolit sekunder. Modifikasi beberapa prosedur isolasi senyawa metabolit sekunder telah dilakukan dalam rangka produksi senyawa metabolit sekunder.
\end{abstract}

Kata Kunci: produksi; senyawa metabolit sekunder; tumbuhan obat

\section{PENDAHULUAN}

Senyawa metabolit sekunder sangat sulit ditemukan dipasaran Indonesia. Sampai saat ini, konsumen senyawa metabolit sekunder di Indonesia biasanya membeli senyawa metabolit sekunder via online dari luar negeri, seperti dari Sigma-Aldrich (www.sigmaaldrich.com), Dhgate (http://www.dhgate.com), dan Chemazone (http://www.chemazone.com). Kelangkaan senyawa metabolit sekunder dipasar dalam negeri tersebut menyebabkan peneliti di perguruan tinggi (dosen dan mahasiswa) atau di lembaga penelitian dan pengembangan harus membeli senyawa metabolit sekunder dari luar negeri dengan harga yang sangat mahal. Bahkan beberapa senyawa metabolit sekunder organisme asli Indonesia sulit ditemukan dipasaran luar negeri karena adanya kekhasan senyawa yang dikandung oleh organisme tersebut. 
Kimia bahan alam merupakan bidang ilmu khusus yang mengkaji tentang metabolit

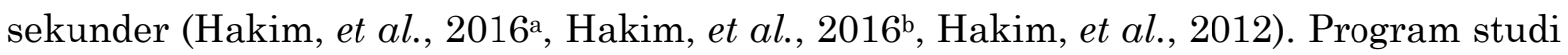
pendidikan kimia, FKIP, Universitas Mataram melaksanakan perkulihan kimia bahan alam yang didukung dengan kegiatan praktikum (3(1) sks). Pelaksanaan praktikum tersebut disusun berdasarkan hasil riset tentang cara mengisolasi metabolit sekunder dari berbagai spesies tumbuhan. Beberapa riset yang telah dilakukan oleh Ketua Tim (Dr. Aliefman Hakim, M.Si) yang didanai oleh Dikti menyangkut prosedur isolasi metabolit sekunder telah banyak melakukan modifikasi dan inovasi terkait dengan cara mengisolasi metabolit sekunder dari berbagai spesies tumbuhan (Hakim, 2008a; Hakim,2008 , Hakim,2009a, 2009b, Hakim, 2010, Hakim, et al., 2010, Hakim \& Jufri 2011, Hakim, et al., 2016a , Hakim, et al., 2016 b). Modifikasi dan inovasi prosedur isolasi metabolit sekunder tersebut telah berhasil memyederhanakan dan menurunkan biaya yang dibutuhkan untuk setiap tahapan isolasi metabolit sekunder dari berbagai spesies tumbuhan.

\section{BAHAN DAN METODE}

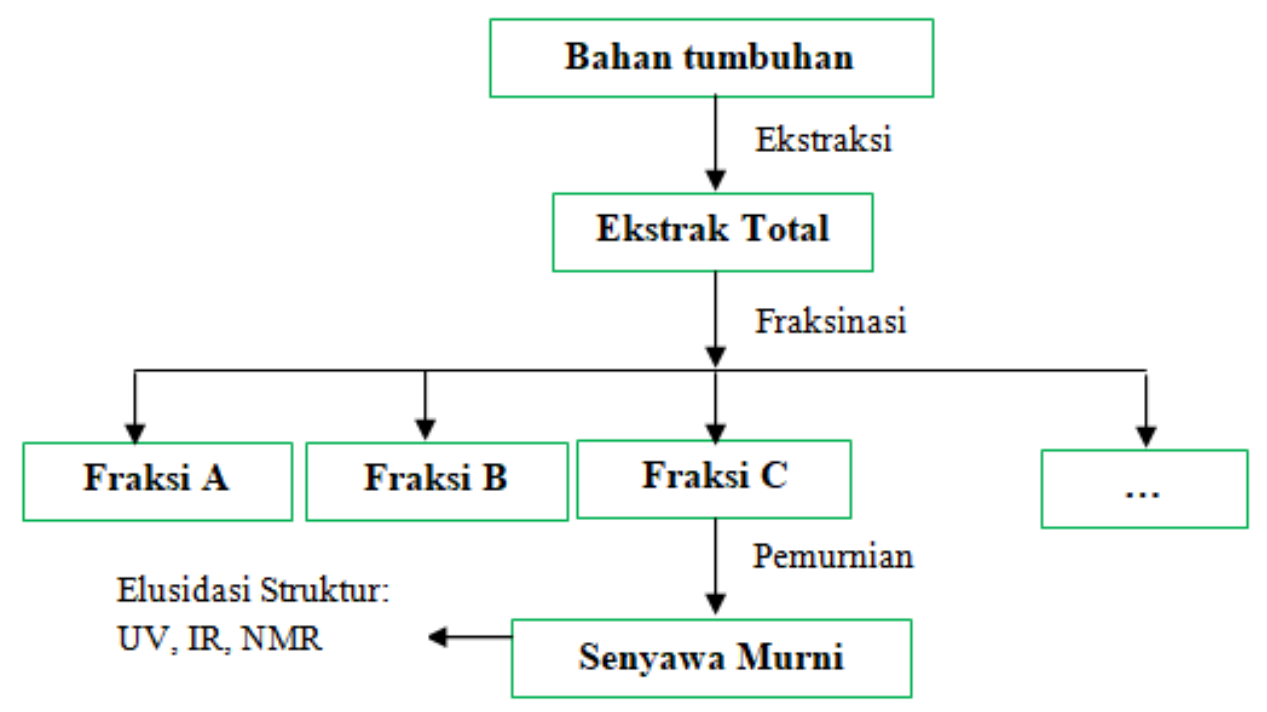

Gambar 1. Prosedur umum isolasi metabolit sekunder

Produk senyawa metabolit sekunder diisolasi dari berbagai spesies organisme asli Indonesia. Senyawa metabolit sekunder tersebut diperoleh melalui langkah-langkah isolasi metabolit sekunder. Meskipun secara umum proses isolasi metabolit sekunder dapat diuraikan menjadi tahap ekstraksi, fraksinasi, pemurnian, dan elusidasi struktur, namun setiap senyawa metabolit sekunder memiliki langkah isolasi dan identifikasi yang berbeda. Senyawa metabolit sekunder yang sama dapat diisolasi dengan cara yang berbeda-beda. Berdasarkan hal tersebut, maka modifikasi untuk mendapatkan senyawa metabolit sekunder dari suatu spesies tumbuhan sangat mungkin dilakukan. Modifikasi tersebut dapat dilakukan pada pelarut, eluen, metode ekstraksi, fraksinasi, maupun pemurniannya. Secara umum metode isolasi senyawa metabolit sekunder dapat dilihat dalam Gambar 1 (Hakim, et al., 2016a). 


\section{HASIL DAN PEMBAHASAN}

Salah satu produk senyawa metabolit sekunder yang telah dihasilkan yaitu: senyawa artocarpin dari sukun (Artocarpus altilis). Struktur senyawa artocarpin dapat dilihat dalam Gambar 2.<smiles>COc1cc2oc(-c3ccc(O)cc3O)c(CC=C(C)C)c(=O)c2c(O)c1C=CC(C)C</smiles>

Gambar 2. Struktur produk senyawa metabolit sekunder

Senyawa metabolit sekunder ini dapat dimanfaatkan untuk penelitian, tugas akhir (skripsi, tesis, atau disertasi), atau keperluan lainnya. Alternatif pemanfaatan senyawa metabolit sekunder dapat dijabarkan sebagai berikut.

1. Bioaktivitas (antibakteri, antijamur, antimalaria, sitotoksik dan lain-lain)

- Membandingkan bioaktivitas senyawa metabolit sekunder dengan ekstrak total tumbuhan (studi literatur bioaktivitas, golongan, dan jalur biogenesis senyawa metabolit sekunder, studi literatur tumbuhan penghasil senyawa metabolit sekunder, uji antibakteri atau antijamur senyawa metabolit sekunder dan ekstrak total tumbuhan)

- Membandingkan bioaktivitas suatu senyawa metabolit sekunder dengan senyawa metabolit sekunder lainnya (studi literatur bioaktivitas, golongan, dan jalur biogenesis dua atau lebih senyawa metabolit sekunder, uji antibakteri atau antijamur dua atau lebih senyawa metabolit sekunder)

2. Bahan baku sintesis kimia

- Melakukan transformasi gugus fungsi suatu senyawa metabolit sekunder (Kajian rancangan sintesis molekul target dari bahan baku senyawa metabolit sekunder, retrosintesis, mekanisme reaksi molekul target, transformasi molekul target di laboratorium, identifikasi molekul target yang dihasilkan)

- Membandingkan bioaktivitas suatu senyawa metabolit sekunder sebelum transformasi gugus fungsi dan setelah transformasi gugus fungsi

3. Kemotaksonomi

Mengkaji keberadaan senyawa metabolit sekunder dalam spesies tumbuhan yang tergabung dalam satu genus dan spesies tumbuhan yang berbeda genus. (Senyawa metabolit sekunder digunakan sebagai penanda dalam spesies tumbuhan tertentu berdasarkan nilai Rf dalam KLT).

\section{SIMPULAN}

Tim telah mampu memproduksi senyawa metabolit sekunder. Salah satunya senyawa artocarpin dari sukun (Artocarpus altilis). Senyawa metabolit sekunder tersebut dapat dimanfaatkan untuk kegiatan penelitian, tugas akhir (skripsi, tesis, atau disertasi), 
atau keperluan lainnya seperti uji bioaktivitas, bahan baku sintesis kimia, kajian kemotaksonomi.

\section{REFERENSI}

Hakim, A. (2008a). Kudraflavon C dari kayu batang Artocarpus scortehinii King. Makalah. Disampaikan pada Seminar Nasional PMIPA FKIP Universitas Mataram. Mataram, 17 Mei 2008.

Hakim, A. $\left(2008^{b}\right)$. "Asam 5-metoksi salisilat dari kayu batang Artocarpus scortehinii King." Jurnal Pijar MIPA. 3, (2), 34-39.

Hakim, A. (2009a). "A Prenylated Flavone from The Heartwood of Artocarpus Scortechinii King (Moraceae)". Indonesian Journal of Chemistry. 9, (1), 146-150.

Hakim, A. $\left(2009^{b}\right)$. Scrining Phytochemistry on The Heartwood and The Root Bark of The Artocarpus camasi (Moraceae) Proceeding of The Third International Seminar on Science Education ISBN: 978-602-8171-14-1 "Challenging Science Education in The Digital Era" October $17^{\text {th }} 2009$.

Hakim, A., Junaidi, E., \& Sani, Y.A. (2010). "Antimalarial Activity and Chemical Analysis of A Secondary Metabolite from Heartwood and Root Bark of Artocarpus camansi Blanco. (Moraceae)". Jurnal Ilmu Farmasi Indonesia. 8, (2), 135-137.

Hakim, A. (2010). "Diversity of secondary metabolites from Genus Artocarpus (Moraceae)". Nusantara Bioscince. 2, (3), 146-156.

Hakim, A. \& Jufri, W. (2011). "Aktivitas Antimalaria dan Analisis Metabolit Sekunder Kayu dan Kulit Batang Artocarpus odoratissimus Blanco. (Moraceae)". Jurnal Bahan Alam Indonesia. 7, (6), 302-305.

Hakim, A., Liliasari, Kadarohman, A. (2012). "Student understanding of Natural Product Concept of Primary and Secondary Metabolites Using CRI Modified". International Online Journal of Educational Sciences. 4, (3), 544-553.

Hakim, A., Liliasari, Kadarohman, A., Syah, Y.M. (2016a). Making a Natural Product Chemistry Course with a Mini Project Laboratory. J. Chem. Educ., 93 (1), 193-196.

Hakim, A., Liliasari, Kadarohman, A., Syah, Y.M. (2016 b). Effects of the Natural Product Mini Project Laboratory on the Students Conceptual Understanding. Journal of Turkish Science Education. 13 (2), 27-36. 